Прегледни чланак

656.1:614.8.084(094.2)

doi:10.5937/zrpfns52-19047

Ágnes B. Juhász, Ph.D., Assistant Professor

University of Miskolc

Faculty of Law

civagnes@uni-miskolc.hu

\title{
THE REGULATORY FRAMEWORK AND MODELS OF SELF-DRIVING CARS*
}

Abstract: Until recent years, it seemed so futuristic that the time would come when no drivers would be needed and cars would drive themselves. Today, the existence of so-called self-driving cars (in other words, autonomous or automated cars) and their participation in road transport is reality, and that raises countless legal and ethical questions.

This study reviews the regulatory frames of these vehicles from several points of view. After the introduction to the international rules on road traffic, attention is given to the current legal provisions adopted in certain states of the USA since these states were the first in the world that attempted to create the legal basis for self-driving cars. After the review of selected American laws, the main tendencies of current and future European regulation will be presented. Among European states, the German regulation amended in 2017 will be examined in detail. Nevertheless, the recent regulatory tendencies of other countries (e.g. Hungary) will be reviewed as well.

Keywords: self-driving vehicle, autonomous car, automated driving system, Vienna Convention, GEAR 2030.

\section{INTRODUCTORY THOUGHTS}

Nowadays, more and more essays and publications analyse the regulatory issues and various aspects of self-driving cars in a comprehensive manner. ${ }^{1}$ In

${ }^{*}$ This research was supported by the project nr. EFOP-3.6.2-16-2017-00007, titled Aspects on the development of intelligent, sustainable and inclusive society: social, technological, innovation networks in employment and digital economy. The project has been supported by the European Union, co-financed by the European Social Fund and the budget of Hungary.

${ }^{1}$ See: Hilgendorf, Eric, Hötitzsch, Sven, Lutz, Lennart: Rechtliche Aspekte automatisierter Fahrzeuge, Nomos, Baden-Baden 2015; Lohmann, Melinda Florina: Automatisierte Fahrzeuge im 
order to create a regulation on self-driving cars, the mapping of the legal questions raised by the appearance of these vehicles is essential. Among these questions, liability issues are the most important. On the one hand, it shall be decided, if the appearance of self-driving cars as innovative solutions requires the introduction of new and special legal institutions or the existing civil law liability solutions can be applied in a satisfactory manner for the compensation of damages caused by these vehicles. ${ }^{2}$ On the other hand, if a national legislator takes a stand on the application of already existing liability constructions, it also shall decide which person is obliged to provide compensation for the damage caused. This person can be either the keeper or the driver of the car, if these are different persons. Nevertheless, the driver's liability raises further questions, since in the case of using a totally automated system or mode, the driver does not actually drive and does not exercise control over the vehicle. It also shall be answered whether the liability is strict or fault-based, i.e. established with regard to the driver's conduct. Moreover, it is also questionable how the liability of the producer of the self-driving car or the built-in software can be inserted into the liability chain. ${ }^{3}$

Liability issues relating to self-driving cars are undoubtedly the most important questions, but other legal aspects shall also be examined. The use of intellectual properties (e.g. software) in the course of the operation of self-driving cars raises questions in the field of copyright law. Furthermore, the installation of so-called 'black box' into self-driving cars, specifically the data recording possibilities of this equipment and the prescription of the data retention duty in order to allow for the reconstruction of an incidental accident caused by the self-driving car, raises further questions. These issues fall within the field of data protection law.

The above-mentioned legal issues are regulated by the various national legislators in different ways. Nevertheless, it is a common feature of these legal regulations that they are always behind the technical reality since the process and rhythm of creating an appropriate legal background is incapable of competing

Lichte des Schweizer Zulassungs- und Haftungsrechts, Nomos, Baden-Baden 2016; Maurer, Markus, Gerdes, J. Christian, Lenz, Barbara, Winner, Hermann (Eds.): Autonomes Fahren Technische, rechtliche und gesellschaftliche Aspekte, Springer, 2015; Oppermann, Bernd, StenderVorwach, Jutta (Eds.): Autonomes Fahren. Rechtsfolgen, Rechtsprobleme, technische Grundlagen, C.H. Becks, München 2017; Juhász, Ágnes, Pusztahelyi Réka: "Legal Questions on the Appearance of Self-Driving Cars in the Road Traffic with Special Regard on the Civil Law Liability", European Integration Studies, 1/2016, 10-28.

${ }^{2}$ Similar dilemmas arise for many innovations that have came into being as result of the so-called Industry 4.0. Seе: Слобода Д. Мидоровић, „Грађанскоправни режим података који настају употребом паметних уређаја“, Зборник радова Правног̄ факулйейа у Новом Саду 2/2018, 663, 664 .

${ }^{3}$ For reasons justifying producer's liability see: Miloš B. Sekulić, “Development Risks - Definition under European Union Law and Justification for Implementation in Serbian Law“, Collected Papers of the Faculty of Law in Novi Sad 2/2018, 800-804. 
with the explosive technological progress that has taken place in the automotive industry in the last few years.

It is a fact that there are regulatory concepts in the world, but these are mostly fragmented, and in the legal practise of European states there is a lack of legal provisions specifically concerning the legal issues of self-driving cars. From a legislative point of view, similar to the US states at the global level, Germany can be regarded as a pioneer at the European level because it was the first state on the continent to adjust the legal environment to technological developments.

On the next few pages, the existing and still evolving regulations on self-driving vehicles are reviewed. Beyond the international rules on road traffic, the related provisions of certain US states and the main features of the EU initiatives will also be presented. After a broad introduction of these regulations, the German solution is to be examined, since the German legislature created not only a framework for the participation of self-driving cars on the road but also attempted to resolve liability issues in connection with possible damage caused by such vehicles with the amendment of the existing German Federal Road Traffic Act.

\section{THE INTERNATIONAL REGULATION BACKGROUND OF ROAD TRAFFIC AND THE LEGAL FRAMEWORK RELATING TO SELF-DRIVING CARS}

The demand for international unification of the rules of road traffic had arisen relatively early. One of the first answers to this demand was the Paris Convention in $1926^{4}$, then the Geneva Convention in 1949, which supplemented and redefined the principles enshrined in the earlier convention in line with developments in the car industry, which revealed a growing concern for road traffic safety. On the other hand, from certain aspects, the Geneva Convention can be deemed a successor of the Paris Convention since it replaced the 1926 Convention in relations between the Contracting and Signatory States.

On $8^{\text {th }}$ November 1968, the Convention on Road Traffic was signed in Vienna (hereinafter referred to as Vienna Convention), which replaced the 1926 and 1949 Conventions in the Contracting States' relations. The Vienna Convention went further than the previous conventions and contains comprehensive international rules on road traffic. Moreover, it requires the Contracting and Signatory States to bring the substance of their domestic legislation in line with the driving rules laid down in it.

Nevertheless, the Vienna Convention has significance not only on the international level. Considering the harmonisation of road traffic regulation within the

\footnotetext{
${ }^{4}$ The Paris Convention was ratified by Hungary by Act XXXII of 1929.
} 
European Union and the creation of future regulation on self-driving cars, it is an important document as well, since the mentioned legal framework can only be worked out in accordance with the principles established in the Vienna Convention. The demand for creating legal provisions on self-driving cars has arisen increasingly on the part of the Member States of the EU. However, creating such regulation was not possible until 2016 since Article 8 of the Vienna Convention prescribed that every moving vehicle or combination of vehicles have a driver. As a general condition, it also prescribed that every driver shall possess the necessary physical and mental ability and be in a physically and mentally fit condition to drive. Moreover, the Vienna Convention prescribed that the drivers of power-driven vehicles possess the knowledge and skill necessary for driving the vehicle.

At the time of its adoption, the Vienna Convention was regarded as a modern document that contained more detailed provisions compared to the rules of the earlier conventions. However, the creators of the convention, because of the state of science and technology of that time, could not reckon with the fact that after a few decades, science and technology would undergo such a significant change that would make it possible for motor vehicles to operate safely on the roads without any human assistance. The jump in technological evolution in parallel with the appearance of new tendencies in the field of motor vehicle improvements make it clear that the revision of the Vienna Convention is indispensable since road traffic regulation, in the lack of an appropriate amendment, could not adapt itself to the regulation demands caused by technological evolution. With awareness of these factors, the Vienna Convention was amended in March 2016 on the initiative of several European countries, including Germany. As a result of this amendment, the previously mentioned Article 8 of the Vienna Convention was also completed with a further paragraph (5bis). At the same time, Article 39 of the convention was also amended.

It can be noted that the main characteristic of these amendments was that they basically did not affect the provisions that prescribe the necessary presence of the driver. In other words, the provision is still in force, according to which every motor vehicle shall have a driver who is able to control the vehicle. Furthermore, it is worthy to note that the amendment also did not affect the definition of the driver. In accordance with this provision, only natural persons can be deemed the "driver" in the application of the Vienna Convention. ${ }^{5}$ Apart from these features, the amendments facilitated the application of various driving assistance systems having effect on the driving of the motor vehicle, provided that such a system complies with the related prescriptions of the United Nations Economic Commission for Europe (hereinafter referred to as UNECE).

The application of systems that are able to control the motor vehicle by the substitution of the human driver has also been recognised. However, in the case

${ }^{5}$ Vienna Convention, Art 1, point (v). 
of the application of such systems, the Vienna Convention provides that the system (i.e. its operation) should be revised by the driver of the car. It means that the driver should have the possibility to change the automated mode to manual mode (e.g. in case of need or in case of avoiding danger) or even to switch off the system operating in automated mode.

Due to the above-mentioned smaller amendments to the Vienna Convention, the self-driving vehicles' presence on the roads is not met with legal difficulties if the conditions set by the Vienna Convention are fulfilled. Nevertheless, with regard to the current technological development tendencies of the motor vehicle industry, the further modification of the Vienna Convention cannot be avoided in the long run. Thus, after reaching the full automatisation of motor vehicles, the driver of the car will not be reasonably expected to exercise permanent control over the car since the application of automated systems is aimed at releasing the driver or preventing traffic accidents caused by negligence.

\section{THE REGULATION OF SELF-DRIVING CARS IN THE UNITED STATES}

On a world scale, the United States leads the way in regulating self-driving cars. This prominent role has both technological and legal reasons. On the one hand, thanks to technological developments, the first self-driving vehicles (e.g. Google's car ${ }^{6}$ appeared in the USA. On the other hand, the USA ratified only the Geneva Convention of 1949 and did not sign the Vienna Convention. Since the provisions of the former convention are more lenient, the national legislator's scope for action in creating rules for road traffic was less limited compared to the possibilities of those states who signed and ratified the Vienna Convention. ${ }^{7}$

At the very start, provisions on self-driving cars were worked out by state legislatures, mostly in the form of bilateral agreements between the states. At present, a kind of federal regulation exists, which originates from the National Highway Traffic Safety Administration of the USA (hereinafter referred to as NHTSA). However, this regulation contains only minimum rules and mostly determines the standards of motor vehicle safety (Federal Motor Vehicle Safety Standards, hereinafter referred to as FMVSS). Thus, the working out and adoption of detailed legal provisions on self-driving cars takes place at state level and will continue to take place on that level, i.e. the legal framework of self-driving cars still has two levels in the USA.

${ }^{6}$ Vö.: Beiker, Sven: History and Status of Automated Driving in the United States, In: Meyer, Gereon, Beiker, Sven (Eds): Road Vehicle Automation. Springer, Cham 2014, 61-70.

${ }^{7}$ The relationship between the international conventions and the federal and state rules are examined in detail by Bryant Walker Smith. See Smith, Bryant Walker: "Automated Vehicles Are Probably Legal in the United States”, Texas A\&M Law Review, 1/2014, 411-521. 
In 2011, Nevada was the first among the 50 states of the USA and in the world to adopt legal provisions on self-driving vehicles. ${ }^{8}$ Over the following two years, similar regulations were created in Florida ${ }^{9}$, California ${ }^{10}$ and Michigan ${ }^{11}{ }^{12}$. Afterwards, in the last few years, more states have recognised the need for regulating self-driving vehicles. The regulations of Nevada, Florida, California and Michigan were considered models by the other states during the working out of their own legal provisions on the presence of self-driving cars in road traffic. Currently 33 states of the USA have some kind of legal regulation related to self-driving vehicles even though the level of these regulations is different. ${ }^{13}$ Nevertheless, the number of regulations facilitating the appearance of self-driving cars on public roads and keeping the legal basis is expected to increase in the next few years.

The legal questions covered by the state regulations in force are mostly similar due to the fact that all of the state legislators worked out their legal provisions on the basis of the regulations of Nevada. However, the method of regulation depends on the time of the adoption of the regulation. At the beginning of the 2010s, provisions relating to self-driving vehicles were put in a single legal document. (See for example in the states of Kentucky ${ }^{14}$, Maine ${ }^{15}$ and Nebraska ${ }^{16}$ ). Contrary to this, in the last two years the 'old' regulations containing minimum rules were completed by new provisions, which were put in separate legal documents.

It can be considered as a common feature that all of the various legal regulations contain the definition of a self-driving vehicle, even though the denomination is different. In view of the practice, the use of the expression "autonomous vehicle" is the most general, but the names of "automated vehicle", "automated driving system-equipped vehicle" and "automated motor vehicle" are also known and used. Though these expressions are more or less overlapping, their exact in-

${ }^{8}$ Assembly Bill (AB) 511 (2011), Senate Bill (SB) 313 (2011).
${ }^{9}$ House Bill (HB) 1207 (2012).
${ }^{10}$ Senate Bill (SB) 1298 (2012).
${ }^{11}$ Senate Bill (SB) 169 (2013), Senate Bill (SB) 663 (2013).
${ }^{12}$ About the above-mentioned regulation, see in detail: Smith pp. 501-508.
${ }^{13}$ During the time after 2013, beyond Nevada, Florida, California and Michigan, high-level regulation (e.g. acts) of self-driving vehicles was adopted in 18 other states (Alabama, Arkansas, Colorado, Connecticut, Georgia, Illinois, Indiana, Louisiana, New York, North Carolina, North Dakota, Pennsylvania, South Carolina, Tennessee, Texas, Utah, Virginia and Vermont) and in the capital, Washington, D.C. Legal sources issued by the governor contain the rules for self-driving vehicles in 10 other states (Arizona, Delaware, Hawaii, Idaho, Maine, Massachusetts, Minnesota, Ohio, Washington and Wisconsin). About the state laws in force, see http://www.ncsl.org/research/ transportation/autonomous-vehicles-self-driving-vehicles-enacted-legislation.aspx (Date of download: $26^{\text {th }}$ September 2018).

${ }^{14}$ Senate Bill 116 (2018).

${ }^{15}$ House Paper (HP) 1204 (2018), Legislative Document (LD) 1724 (2018).

${ }^{16}$ Legislative Bill (LB) 989 (2018). 
terpretation is supported by further essential and various notions (e.g. "autonomous technology", "operator", "automated mode", "automated driving system", etc.).

State regulations typically determine the conditions of the testing of self-driving vehicles on public roads by their producer and prescribe the requirements of the real (i.e. 'live', 'non-testing') appearance of such vehicles in public road traffic. ${ }^{17}$ The testing of these motor vehicles is possible only with the possession of permission and a temporary distinctive license plate. Moreover, a self-driving car can be tested only in a certain geographical area determined in the above-mentioned permission.

In relation to the testing, regulations also prescribe that the producer (tester) of the self-driving vehicle must have insurance for a certain amount (e.g. the amount insured should be at least $\$ 5$ million in Nevada and California).

Furthermore, state regulations contain provisions on the driving licenses, since it was questionable, if the operation of a self-driving vehicle requires a special driving licence or whether having a traditional license is enough. Opinions are diverging. Some people have said that the existence of various new functions which are built into the motor vehicles requires new competences for the driver in a given case, therefore the introduction of a new kind of driving license is necessary. The question is regulated quite differently by the states. In California, the operation of self-driving vehicles requires a special type of driving license, which can be obtained in a special driving course regulated by the state. In Florida, there is no further requirement for the driving of such vehicles ${ }^{18}$, while the normal driving license shall be endorsed by the competent authority in Nevada. ${ }^{19}$ The rules on driving license are fairly different in North Carolina, where the operation of self-driving vehicles does not require any kind of driving license at all. ${ }^{20}$ Nevertheless, the regulation in force prescribes that the presence of an adult is needed when a person under the age of 12 is seated in the motor vehicle.

According to the FMVSS, state regulations contain further provisions prescribing the requirement for the producer to provide self-driving vehicles with such equipment (a 'black box') that is capable of storing sensor data from at least

${ }^{17}$ Soriano, Bernard C., Dougherty, Stephanie L., Soublet, Brian G., Triepke, Kristin J.: Autonomous Vehicles: A Perspective from the California Department of Motor Vehicles, In: Meyer, Gereon, Beiker, Sven (Eds): Road Vehicle Automation. Springer, Cham 2014, 15-24 and 21-22; Nowakowski, Christopher, Shladover, Stephen E., Chan, Ching-Yao, Tan, Han-Shue: "Development of California Regulations to Govern the Testing and Operation of Automated Driving Systems", Transportation Research Record, Vol. 2489 (2015): Intelligent Transportation Systems and Connected and Automated Vehicles, 137-144.

${ }^{18}$ L. House Bill (HB) 7027 (2016).

${ }^{19}$ See Peck, Spencer, Fatehi, Leili, Douma, Frank, Lari, Adeel: "The SDVs Are Coming! An Examination of Minnesota Laws in Preparation for Self- Driving Vehicles", Minnesota Journal of Law, Science \& Technology, 2/2015, 843.

${ }^{20}$ House Bill (HB) 469 (2017). 
30 seconds before a collision in a read-only format. Beyond this, the regulations prescribe a duty for the producer of a self-driving car to equip the vehicle with other systems that are able to alert the driver and indicate the malfunction of the automatic mode and enable the driver either to intervene in the operation of the vehicle or to take over control of the motor vehicle. In accordance with the FMVSS, self-driving vehicles shall also be equipped with such a system that enables the vehicle to come to a complete stop if the driver is unable to take control. ${ }^{21}$

After a rough review of US regulation tendencies on self-driving vehicles, several conclusions can be drawn.

1. Although even more states are adopting their own legal provisions, the demand for the regulation of self-driving vehicles arises primarily in the most developed regions of the USA. The experiences of the last few years show that resolving the questions of self-driving vehicles is an important aim for state legislators. Nevertheless, the "rhythm" and the directions of the state legislatures are diverging, and certain states are pretty much ahead of others.

2 . The necessity of creating regulation on self-driving cars is beyond debate in several states of the USA. In California, for example, self-driving cars are already allowed not only to test on public roads but to be used in open road traffic if the vehicle complies with the FMVSS. Similarly, since 2016, self-driving vehicles can also be used on the roads of Florida in non-testing mode, provided that these vehicles meet the requirements of the FMVSS. A further and controversial feature of the Floridian regulation is that it does not require the presence of the driver in the self-driving car. ${ }^{22}$ Nevertheless, this provision is not unique, since the presence of a driver is also not required for the operation of a self-driving car under a related bill in Michigan. ${ }^{23}$ Furthermore, according to the regulations Nebraska adopted in 2018, the driver's presence in the vehicle is not compulsory for open road use if the prerequisites defined by the law are fulfilled. ${ }^{24}$

3. After reviewing the relating regulations of the various US states, it should be stated that these provisions can serve as models for the world's other developed countries that are concerned by the appearance of self-driving cars and the legal and other problems they pose. ${ }^{25}$ However, as it can be seen, legal provisions on self-driving cars are very divergent in the USA. Therefore, a question arises: Is there ever any chance to create such a globally harmonised legal framework that

${ }^{21}$ Soriano, Dougherty, Soublet, Triepke, 22.

${ }^{22}$ House Bill (HB) 7027 (2016).

${ }^{23}$ Senate Bill (SB) 996 (2016).

${ }^{24}$ Legislative Bill (LB) 989 (2018).

${ }^{25}$ In connection with the state regulations, the adopted legal provisions are often criticised for not distinguishing among the self-driving cars according to the level of automatisation, i.e. these regulations are not as differentiated as required. See Pearl, Tracy Hresko: "Fast \& Furious: The Misregulation of Driverless Cars", Annual Survey of American Law, 1/2017, 58. 
takes the form of an international convention? As Pearl noted in her previously referenced work, state legislators should change their approach and wait, see and then legislate instead of adopting anticipated legislation. ${ }^{26}$

\section{EUROPEAN TENDENCIES IN THE REGULATION OF SELF-DRIVING CARS}

In the last few years, the USA has had to face several rivals in the development of self-driving vehicle technology. In the Far East, namely in China and Japan, a large amount of money is spent on motor vehicle improvement; the creation of the appropriate legal environment is coming forth in the near future. Though technological developments also take place in Europe, the future regulation of self-driving vehicles shall be examined from several viewpoints and levels in this region. This is caused by the fact that distances in Europe are relatively small, i.e. travelling is necessarily coupled with the crossing of borders. Therefore, the appearance of self-driving motor vehicles on European roads brings up the demand for relatively unified, or at least harmonised, legal regulation. It would be the best solution if technical and legal questions related to self-driving vehicles would be regulated not at the national (or Member State) level but at the supranational level. However, a future regulation to be adopted by the European Union would cover the European continent only in part. Thus, the creation of such a legal framework would not be a satisfactory solution since the crossing of the external borders of the EU with a self-driving car raises further questions that can be arranged only by means of bilateral agreements.

Since transport policy forms part of the common policies of the European Union, the designation of the main directions of regulation of the various sectors (e.g. road transport, railway transport, aerial transport and navigation) falls within the competence of the EU. Therefore, the minimum rules on self-driving cars will presumably be worked out at the EU level. However, road transport is regulated at the national level by all Member States, in line with the previously mentioned international road traffic conventions. ${ }^{27}$

In the middle of the 2000s, a European Technology Platform (ETP) was set up with the recognition and support of the European Commission. As main tasks, the European Road Transport Research Advisory Council (hereinafter referred to as ERTRAC) cooperates with the actors of the road transport sector to create a common approach and to shape the image of the future of European road transport. At the same time, it drafts the possible strategies and the main directions of

\footnotetext{
${ }^{26}$ T. Pearl, 71.

${ }^{27}$ In Hungary, Act No. I. of 1988 contains provisions on road transport.
} 
research and development in the field of road transport. ${ }^{28}$ National road transport strategies are worked out along these lines.

However, during the last few years, the Commission has expressed that it intends to create an intelligent transport system that is in step with technological developments and utilises recent achievements in the field of the motor vehicles as an industry having strategic importance. Moreover, the system to be worked out within the European Union should comply with the various aims (e.g. sustainability) of the EU. ${ }^{29}$ Towards the realisation of this goal, the Commission launched several projects (e.g. HAVEit, Interactive, AdaptIVe, i-GAME, AutoNOMOS, etc.), which concern the development and testing of self-driving vehicles. ${ }^{30}$

In October 2015, the Commission set up the High Level Group on the Competitiveness and Sustainable Growth of the Automotive Industry in the European Union (hereinafter referred to as GEAR 2030), consisting of 25 members who are experts from different sectors. Moreover, certain members of the Commission, certain Member States' ministers of economy, industry or transport, representatives of consumers, trade unions, environmental protection and road safety organisations (e.g. the European Association of Automotive Suppliers, the European Federation for Transport and Environment, the European Consumer Organisation, etc.) and observers of other organisations (e.g. the European Investment Bank, the Committee of the Regions, the European Economic and Social Committee) also participated in the work of GEAR 2030.

In 2016, GEAR 2030 prepared a discussion paper for the Commission (Roadmap on Highly Automated Vehicles) ${ }^{31}$, in which the working group defined the need for the revision and amendment of the legal and political framework of highly automated motor vehicles. According to GEAR 2030's paper, the above-mentioned need is especially strong in the field of traffic rules, while provisions on the acquisition of driving license, road conformance, road signs, liability and insurance, as well as cyber security and data protection, shall also be revised or amended. As GEAR 2030 formulated, the final goal is the creation of a common

${ }^{28}$ About the tasks and activities of the ERTRAC, see the organisation's homepage (www. ertrac.org.).

${ }^{29}$ See White Paper - Roadmap to a Single European Transport Area - Towards a competitive and resource efficient transport system, COM (2011) 144 final, Brussels, 28.03.2011; CARS 2020: Action Plan for a competitive and sustainable automotive industry in Europe, COM (2012) 636 final, Brussels, 08.11.2012. About the white paper see Iván Gábor: Közlekedési politika, In: Kende Tamás (Ed.): Bevezetés az Európai Unió politikáiba, Wolters Kluwer, Budapest 2015, 657-660.

${ }^{30}$ See Meyer, Gereon, Deix, Stefan: Research and Innovation for Automated Driving in Germany and Europe, In: Meyer, Gereon, Beiker, Sven (eds): Road Vehicle Automation. Springer, Cham 2014, 71-81 and 73-74.

${ }^{31} \mathrm{https}: / /$ circabc.europa.eu/sd/a/a68ddba0-996e-4795-b207-8da58b4ca83e/Discussion\%20 Paper\%C2\%A0-\%20Roadmap\%20on\%20Highly\%20Automated\%20Vehicles\%2008-01-2016.pdf, (Date of download: $6^{\text {th }}$ April 2018). 
legal foundation that is based on the international standards laid down by the UNECE and harmonised to the highest degree. In autumn 2017, GEAR 2030 published its final report ${ }^{32}$, in which it made recommendations for the Commission and the Member States relating to the future direction of the regulation of automated and connected motor vehicles.

In May 2018, considering the recommendations of the report by GEAR 2030, the Commission published a communication ${ }^{33}$, in which it envisaged the comprehensive revision of vehicle safety regulations ${ }^{34}$ and the adoption of further legislative acts regarding the questions of self-driving cars. Furthermore, EU provisions on driving licenses ${ }^{35}$ should also be amended in the near future due to the appearance of self-driving vehicles in open road traffic. Nevertheless, the direction of these amendments is uncertain at present since it has not been decided yet if the operation of these vehicles, provided that possession of special knowledge is needed, requires a new kind of driving license or not.

It is also important to note that both national legislators and the legislative bodies of the EU should take into consideration the amended and newly inserted provisions of the Vienna Convention in the course of the adoption of their regulations on self-driving vehicles.

It is obvious that the revision of the EU regulations on road traffic is necessary because of the appearance and the future use of self-driving cars. Beyond this need, the potential directions of the revision became even more concrete in the last few years, therefore it should be taken into account that various legal regulations will be adopted in the EU, even if there has not been any explicit legal initiative up to now. EU legislation has its own time. While the creation of a single EU regulation on self-driving cars will be a long, gradual and very slow process, several political declarations have been published at the national level in which the introduction of self-driving vehicles and the adoption of the regulatory framework have been scheduled. The activity of national legislators is also due to the pressure from leading motor vehicle producers since the existence of a clear, safe and predictable legal environment is particularly important to them. These manufacturers expect for good reason to see how and under which conditions the testing

32 https:/ec.europa.eu/growth/content/high-level-group-gear-2030-report-on-automotivecompetitiveness-and-sustainability_en, (Date of download: 18 ${ }^{\text {th }}$ June 2018).

${ }^{33}$ Communication from the Commission - On the road to automated mobility: An EU strategy for mobility of the future, COM (2018) 283 final, Brussels, 17.05.2018.

${ }^{34}$ Regulation (EC) No 661/2009 of the European Parliament and of the Council of 13 July 2009 concerning type-approval requirements for the general safety of motor vehicles, their trailers and systems, components and separate technical units intended therefore, OJ L 200, 31.7.2009, pp. 1-24.

${ }^{35}$ Directive 2006/126/EC of the European Parliament and of the Council of 20 December 2006 on driving licences,

OJ L 403, 30.12.2006, pp. 18-60. 
and the open-road use of automated vehicles or vehicles equipped with driving assistance technologies will occur.

Nowadays, there are more states that are interested in the introduction of self-driving vehicles, and that manifests this intention at the political level. However, there are also some states where the adoption of the related provisions or the modification of previously existing regulations is in process or has already occurred. For the present, the application of the latter solution, i.e. the amendment of the existing rules, is more common since the testing of self-driving vehicles (limited to a certain section of road and only in possession of a special permit) typically requires the appropriate amendment to road traffic rules.

In the Netherlands, for instance, road traffic rules were amended; since summer 2015, the wide open-road testing of self-driving vehicles (both cars and buses) is possible in possession of a permit from the competent authority.

In Hungary, some steps have also been taken recently towards the future introduction of self-driving cars. In 2017, amendments to two ministerial decrees (Ministerial Decree KöHÉM No. 5/1990 of 12 April 1990 on the technical inspection of road vehicles and Ministerial Decree KöHÉM No. 6/1990 of 12 April 1990 on the technical conditions for placing and keeping road vehicles in circulation) were adopted ${ }^{36}$ in relation to the testing of vehicles for experimental purposes. Thereafter the open-road testing of these vehicles became legal in Hungary.

It should be noted that Hungarian regulations use neither the expression 'self-driving vehicle' nor the term 'automated vehicle'. As an alternative, Hungarian legislators introduced a broader expression. An 'autonomous vehicle for experimental purposes' is such a vehicle for experimental purposes that (a) is aimed at the development of partially or fully automated operation and (b) has a qualified test driver who, depending on the level of automatisation of the vehicle, can exercise manual control when it is needed in cases that jeopardise traffic safety. ${ }^{37}$

Annex 18 of Decree No. 6/1990 contains the classing of the above-mentioned vehicles in line with internationally defined and recognised taxonomy. ${ }^{38}$ Annex 17 of the same decree contains the detailed operational and technical conditions relating to autonomous vehicles with the aim of development. ${ }^{39}$

${ }^{36}$ Ministerial Decree NFM 11/2017 of 12 April 2017 amending the Ministerial Decree KöHÉM No. 5/1990 of 12 April 1990 on the technical inspection of road vehicles and Ministerial Decree KöHÉM No. 6/1990 of 12 April 1990 on the technical conditions for placing and keeping road vehicles in circulation in relation to the testing of vehicles for experimental purposes.

${ }^{37}$ See Decree No. 5/1990, Article $\$ 2$ (3b), point b).

${ }^{38}$ In 2014, the Society of Automotive Engineers (SAE) International published a standard by which the definition of autonomous motor vehicles and the five levels of automatisation were determined. See Taxonomy and Definitions for Terms Related to Driving Automation Systems for On-Road Motor Vehicles, https://www.sae.org/standards/content/j3016_201806/).

${ }^{39}$ Annex 17 of the Decree No. 6/1990 contains provisions on the expected status of the autonomous vehicle for experimental purposes and prescribes the requirement of prior notification 
Regarding the regulation of self-driving cars at the European level, Germany is clearly a pioneer. The German legislation has already established the legal framework in which the participation of self-driving cars on the road is possible, despite the fact that until now there has been no adopted legislation at the EU level. Since the adopted legislation in Germany is unique at the European level and can be an example for other national and EU legislators, the main provisions will be described in more detail below.

\section{THE GERMAN MODEL OF THE REGULATION OF SELF-DRIVING CARS}

In the last few years, the demand for national regulation of self-driving vehicles has been growing even stronger in Germany in parallel with the great leap forward in the technology of automated and self-driving motor vehicles. The leading German motor vehicle producers (e.g. Mercedes (Daimler), BMW, Audi, Volkswagen, etc.) presented their innovative solutions and the prototypes of self-driving cars, as well as the testing on the open road and the use in road traffic of such vehicles that have been built to serve future generations, required for clear and precisely defined frames. In recent times, the attention of lawyers also turned toward the direction of self-driving vehicles and problems generated by their appearance. They tried to draft a solution for all of those questions that arose due to the appearance of self-driving vehicles and to the lack of their appropriate regulation..$^{40}$

In November 2015, the Federal Government of Germany (Bundesregierung) published a strategy ${ }^{41}$ which defined the need for the modification of road traffic regulations in order to make the use of self-driving cars on the road possible. Afterwards, the government proposed a draft ${ }^{42}$ to the Bundestag, according to which the German Road Traffic Act (Straßenverkehrsgesetz, hereinafter referred

of testing in autonomous mode to the Minister of Transport. It also prescribes that the vehicle developer shall provide a data recorder in autonomous vehicles with the aim of development that can record the digital signals from the movement of the vehicle and can reconstruct events in the case of a road accident. The Annex settles the requirements of the switching system between manual control and automatic control.

${ }^{40}$ Franke, Ulrich: "Rechtsprobleme beim automatisierten Fahren - ein Überblick", Deutsches Autorecht, 2/2016, 61-66; Jänich, Michael Volker - Schrader, Paul - Reck, Vivien: "Rechtsprobleme des autonomen Fahrens", Neue Zeitschrift fuer Verkehrsrecht, 7/2015, 313-318.

${ }^{41}$ See Strategie automatisiertes und vernetztes Fahren, https://www.bmvi.de/SharedDocs/ DE/Publikationen/DG/broschuere-strategie-automatisiertes-vernetztes-fahren.html (Date of download: $17^{\text {th }}$ June 2018), p. 17.

${ }^{42}$ About the draft of the amendment of the StVG, see in detail Berndt, Stephan: "Der Gesetzentwurf zur änderung des Strassenverkehrsgesetzes. Ein Überblick”, Strassenverkehrsrecht, 4/2017, 121-127. 
to as $S t V G$ ) was amended in $2017 .{ }^{43}$ With the adoption of this amendment, the German legislature paved the way for the safe introduction of vehicles equipped with automated functions to the open road traffic.

The new Article §la of the StVG contains the basic provisions on automated motor vehicles, distinguishing between motor vehicles with highly or fully automated driving functions. As a starting point, Article §1a establishes that the operation of a motor vehicle with highly or fully automated driving function is permissible provided the function is used for its intended purpose. In addition, the referenced article of the StVG defines the conceptual framework of the above-mentioned motor vehicles. In the application of the StVG, those motor vehicles shall be deemed as motor vehicles with highly or fully automated driving functions, which are equipped with technical equipment that is able to perform, after activation, driving tasks in compliance with traffic laws. The definition set by the act also specifies that the automated system can be manually overridden or deactivated by the driver at any time. It is laid down as a further requirement that the necessity of manual vehicle control can be recognised by the driver, who is to be alerted visually, acoustically, tactilely or otherwise perceivably by the automated system. In case of alert, the automated system shall ensure enough time for the driver to take control over the motor vehicle. ${ }^{44}$

It is also important to note that the definition of motor vehicles with highly or fully automated driving functions diverge from the notion used by the US state regulations. The definition of the $\mathrm{StVG}$ is more complex since it requires not only the existence of automated driving function and the possibility of taking over control of the car but also the fulfilment of other conditions. Moreover, the StVG determines who shall be deemed a driver. According to Article §1a (4), a driver can be anyone who activates a highly or fully automated driving function and uses such a function for vehicle control, even if he does not control the vehicle manually by himself during the time of the intended use of the automated function. Due to the application of a fiction, the notion of driver also covers those persons who actually do not exercise control over the motor vehicle. This is the reason why the general road traffic requirements for drivers shall be applied to the driver of motor vehicles with highly or fully automated driving functions. ${ }^{45}$

The amended text of the StVG also defines the basic rules for the relationship existing between the driver and the highly or fully automated motor vehicle. These provisions determine those rights and duties (responsibilities) that can be exercised

${ }^{43}$ About the new provisions of the StVG, see Hilgendorf, Eric: "Auf dem Weg zu einer Regulierung des automatisierten Fahrens: Anmerkungen zur jüngsten Reform des StVG", Kriminalpolitische Zeitschrift, 4/2017, 225-228 and König, Carsten: "Die gesetzlichen Neuregelungen zum automatisierten Fahren”, Neue Zeitschrift für Verkehrsrecht, 3/2017, 124-128.

${ }^{44} \mathrm{StVG}$, Art 1a (2).

${ }^{45}$ E. Hilgendorf, 226. 
or shall be fulfilled by the driver during the use of the motor vehicle in automated mode. Nevertheless, these rights and duties have an additional aspect since they, because of the normative extension of the notion of driver, complement those rights and duties which are generally prescribed for drivers of traditional motor vehicles.

Article $\S 1 \mathrm{~b}(1)$ of the StVG provides for the driver to divert his attention from the road traffic occurrences and vehicle control when the vehicle is controlled by means of highly or fully automated driving functions. However, the driver shall remain alert at any time to fulfil his duty prescribed by law, i.e. to take over control of the car.

According to the paragraph (2) of Article $\S 1 \mathrm{~b}$, the driver is obliged to take control of the motor vehicle without delay if he is expressly asked to by the automated system or he himself recognises or on the basis of obvious circumstances should recognise that the prerequisites for the intended use of automated driving functions no longer exist. ${ }^{46}$

Beyond the general rules of motor vehicles with highly or fully automated driving functions, the StVG also contains special provisions regarding data management (\$63a). These rules have been strongly criticised in the literature. ${ }^{47}$

During the use of highly or fully automated driving functions, some data is stored by means of the satellite navigation system. Among others, motor vehicles store information on the exact time and place (i.e. coordinates) when a change of vehicle control between the (human) driver and the highly or fully automated system takes place. Moreover, the system records the time when the driver is asked to take over or take back control of the vehicle, or when a technical failure or malfunction occurs. According to Article $\S 63 \mathrm{a}$ (4), the owner of the vehicle shall delete the data stored after six months. Nevertheless, in certain cases (e.g. in case of a traffic accident), this data can be transmitted to the authorities. In those cases, the owner of the vehicle is obliged to delete the data stored (and transmitted) after three years.

Though the German legislature amended several provisions of the StVG regarding motor vehicles with highly or fully automated driving functions, the modification did not concern issues of liability. The liability of the driver is essentially based on Article $\$ 823$ of the German Civil Code (Bürgerliches Gesetzbuch, hereinafter BGB) and $\S 18$ of the StVG. However, beyond such general delictual

46 The above-mentioned paragraph of the StVG was strongly criticised by specialists. See Wagner, Bernd, Goeble, Thilo: "Freie Fahrt für das Auto der Zukunft? Kritische Analyse des Gesetzentwurfs zum hoch- und vollautomatisierten Fahren", Zeitschrift für Datenschutz, 6/2017, 265; Schirmer, Jan-Erik: "Augen auf beim automatisierten Fahren! Die StVG-Novelle ist ein Montagsstück", Neue Zeitschrift für Verkehrsrecht, 6/2017, 255.

${ }^{47}$ Schmied, Alexander, Wessels, Ferdinand: "Event Data Recording für das hoch- und vollautomatisierte Kfz. Eine kritische Betrachtung der neuen Regelungen im StVG", Neue Zeitschrift fuer Verkehrsrecht, 8/2017, 357-364. 
(fault-based) liability, the rule of strict liability can also be applied as it is prescribed by Article $\S 7$ of the StVG. The application of strict liability in the case of damage caused by a motor vehicle is widespread in European liability systems. Nevertheless, the use of motor vehicles with highly or fully automated driving functions raises the question of whether the application of such a form of liability shall be rethought. As Hilgendorf noted in his already mentioned work, the German legislature should have redefined the existing liability structure with regard to highly or fully automated motor vehicles. Since such modification was not adopted, the keeper of a highly or fully automated vehicle is still liable for the damage caused by his vehicle under strict liability rules according to the related provisions of the StVG. However, while the driver can be exonerated from liability if the automated driving function was used and the damage was caused by the malfunction of the automated driving system, this exoneration cannot be applied to the keeper. Hilgendorf also added that other legal acts like the German Product Liability Act ${ }^{48}$ and the related provisions of the German Criminal Code ${ }^{49}$ have not been amended. ${ }^{50}$ Accordingly, in the case of a defect of a product, the producer or the operator of the technological system can be liable for the damage. Such liability is also based on fault. In his recent work, König agrees with the opinion of Hilgendorf and emphasizes that rules about the liability of the keeper, driver and producer should have been created. ${ }^{51}$

As it was mentioned, the amendments and the newly inserted provisions of the StVG have been strongly criticised by both theoreticians and practitioners. At the same time, it should be noted that the introduction of the new provisions has an experimental nature, as it is shown by Article $\S 1 \mathrm{c}$ of the StVG. According to this Article, after 2019, the competent ministry (i.e. the Federal Ministry of Transport and Digital Infrastructure $)^{52}$ is obliged to revise the application of the amended provisions of the StVG and evaluate the application on the grounds of economic considerations. Afterwards, the ministry is obliged to report the results to the Bundestag.

Nonetheless, it should also be noted that the amended provisions of the StVG, aimed at creating the legal framework for the use of self-driving cars in open road traffic, are unique and exemplary in Europe. Therefore, these new German regulations can serve as a model for other European states in the course of working out their own national regulations on self-driving cars. ${ }^{53}$

${ }^{48}$ Gesetz über die Haftung für fehlerhafte Produkte (ProdHaftG).

49 Strafgesetzbuch (StGB), Art. 222 and Art. 229.

${ }^{50}$ E. Hilgendorf, 227.

${ }^{51}$ König, Cartsten: "Gesetzgeber ebnet den Weg fuer automatisiertes Fahren - weitgehend gelungen”, Neue Zeitschrift fuer Verkehrsrecht, 6/2017, 251.

${ }_{52}$ Bundesministerium für Verkehr unf digitale Infrastruktur, BMVI.

${ }^{53}$ By way of example, the German provisions are examined by Konrad Lachmayer in respect to their practicability for the creation of future Austrian regulation on self-driving cars. 


\section{CLOSING REMARKS}

The automatisation of motor vehicles is a long development process. In the course of such a process, modern technologies like lane-keeping assistance, blind spot detection systems, adaptive cruise control (ACC), autonomous emergency braking system (AEB) or collision avoidance systems have been the first steps. However, these assistance systems were superseded by new science and technology, and such systems that are able to take over full operation (control) of the vehicle for shorter or longer periods have been tested.

With regard to the distribution of driving tasks between the (human) driver and the assistance system, vehicles can be ranked into levels on the basis of the measure of their automatisation. The first level encompasses those motor vehicles that are fully and exclusively controlled by a human driver, i.e. operating tasks like steering, braking, accelerating or slowing down and so forth are performed by the driver. Contrary to this, those vehicles that are at the highest level of automatisation ("fully automated vehicles") are able to drive themselves, i.e. these vehicles do not require human attention (and human presence) since the autonomous vehicle system controls all critical tasks, such as the monitoring of the environment and identification of unique driving conditions like traffic jams, and is capable of allowing safe participation in public road traffic. Although the development of self-driving vehicles is quite fast, their appearance on public roads is only predicted to happen in the 2020 s or 2030 s at the earliest; currently the testing of highly automated vehicle prototypes on public roads is in progress.

At present, national legislators are expected to create regulations on self-driving cars. The law should keep abreast of technological development, even if it is obvious that the legal environment cannot change as fast as the improvement of automated vehicles and other modern technologies. Not only the producers of motor vehicles but also the members of society as a whole need a safe and predictable legal background that designates the legal parameters of automatised systems and defines the ethical and legal requirements to be fulfilled.

Resolving liability questions is indisputably a cornerstone of the regulation to be created in the future. ${ }^{54}$ There is a basic need for designating the borders of

See Lachmayer, Konrad: "Von Testfahrten zum regulären Einsatz automatisierter Fahrzeuge", Zeitschrift für Verkehrsrecht, 12a/2017 (Sonderheft), 519.

${ }^{54}$ De Bruyne, Jan, Tanghe, Jochen: "Liability for damage caused by autonomous vehicles: a Belgian perspective", Journal of European Tort Law, 3/2017, 324-371; Gomille, Christian: "Herstellerhaftung für automatisierte Fahrzeuge”, Juristen Zeitung, 2/2016, 76-82; Harnoncourt, Maximilian: "Haftungsrechtliche Aspekte des autonomen Fahrens", Zeitschrift für Verkehrsrecht, 12a/2016, 546-552; Schrader, Paul: "Haftungsfragen für Schäden beim Einsatz automatisierter Fahrzeuge im Straßenverkehr", Deutsches Autorecht, 5/2016, 242-246; Templ, Heinz: "Über die Haftungsfrage von selbsttätig am Straßenverkehr teilnehmenden KFZ", Zeitschrift für Verkehrsrecht, 1/2016, 10-14. 
the liability of the (vehicle) keeper and driver, the producer of the vehicle or the built-in automated driving system and the operator of the technological system. Furthermore, defining the relationship among these liability forms is also essential. The clear designation and delimitation of civil (law) liability cases is undoubtedly the most urgent task. Nevertheless, questions also emerge in other fields of liability (e.g. criminal law and administrative law) to be answered in the near future. ${ }^{55}$

The existence of self-driving cars is not futurity but reality, therefore the creation of the appropriate regulatory environment is necessary, both at the national and supranational level. National legislators should start from already existing (e.g. German, American) regulation and, learning from their noticed deficiencies, should aim to create such a legal framework that satisfies the needs that arise and arranges more broadly the questions relating to the use of self-driving vehicles in open road traffic.

${ }^{55}$ Bartolini, Cesare, Tettamanti, Tamás, Varga, István: “Critical features of autonomous road transport from the perspective of technological regulation and law", Transportation Research Procedia, 17/2017, 796-797. 


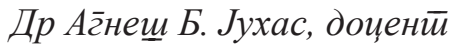
Универзитетей у Мищколиу

Правни факулиетеи

civagnes@uni-miskolc.hu

\section{Регулаторни оквир и модели аутомобила који сами возе}

Сажейик: До недавно је иоомисао да ће доћи време када неће битии йойребе за возачима и када ће аутиомобили сами возитии деловала одвище фу-

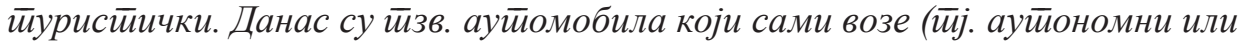

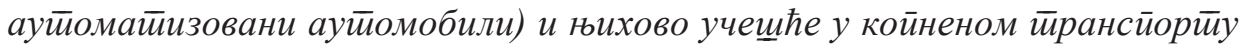

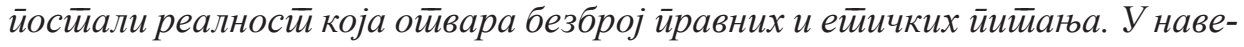

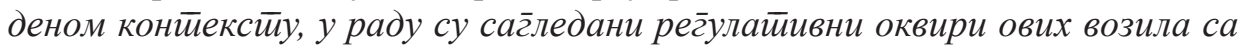
неколико тиачака г ледищйа. Након уводног̄ дела у коме су изложена међународна ирравила койненог̄ саобраћаја, йжж а је йосвећена важећим одредбама усвојеним у йојединим америчким државама, с обзиром на тио да су ове

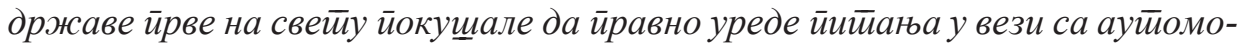
билима који сами возе. Након иррег̃леда одабраних иррава америчких држава, ирредстиављене су кључне тиенденције у важећој и будућој евройској регуулаиииви. Међу евройским земљама, немачка регуулайива са изменама из 2017.

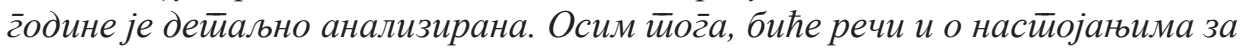
ирравно уређење ове областии и у друг̄им земььма йойуй Мађарске.

Кључне речи: возила која сама возе, аутиономни ауйомобили, системе ауйомайске вожње, Бечка конвенција, GEAR 2030.

Датум пријема рада: 03.10.2018. 